\title{
Effectiveness of Maja Leaf (Aegle Marmelos) Extract to The Process of Infertilization
}

\author{
Ima Rahmawati, Emyk Windartik, Eka Nur Soemah, IfaRoifah \\ Bina Sehat PPNI Health Science Institute of Mojokerto \\ Email:emykimoet@yahoo.com
}

\begin{abstract}
Modern contraceptives were widely used derived from steroids and potentially invite side effects such as weight gain, menstrual cycle disorders, nausea and elevated blood pressure. Currently, the community began to switch traditional herbs are relatively safer. Maja Leaf (Aegle Marmelos) contain many fitosteroles ( $\beta$-sitosterol and stigmasterol) one of its functions is hormonal contraception by inhibiting the process of ovulation. This research aims to know the effect of Maja Leaf (Aegle Marmelos) extract on ovarian weight and corpus luteum number of the female white rat. The research design of posttest only control group design with animal tries Hundred norvegicus female type, aged 8-10 months, weight 200-250g counted 24 tail divided 4 group. After the vaginal smear is done in the same phase of the proestrus for 12 days, the animals try to be treated with Maja Leaf (Aegle Marmelos) extract. Rats in group 1 (K1) control group, in group 2 (K2) were given Maja Leaf (Aegle Marmelos) extract dose 0,5g/kgBB, group 3 (K3) were given Maja Leaf (Aegle Marmelos) extract dose 1g/ $\mathrm{kgBB}$ and group 4 (K4) were given Maja Leaf (Aegle Marmelos) extract dose of $1.5 \mathrm{~g} / \mathrm{kgBB}$. At the end of the study all rats were taken ovaries for weight and number of corpus luteum. Analysis with Anova-oneway. Anovaone-way analysis results show $\mathrm{p}$-value $<0,05$ so it can be concluded that there is a significant difference between K1 and K3. This research can be concluded Maja Leaf (Aegle Marmelos) extract effectively decrease ovarium weight and corpus luteum amount in female white rat. In Maja Leaf (Aegle Marmelos) extracts can inhibit follicular development through suppression of FSH levels resulting in reduced number of follicles and corpus luteum ovaries. Many at least the corpus luteum is closely related to the amount of ovum being ovulated.
\end{abstract}

Keywords: Corpus luteum, maja Leaf (Aegle Marmelos), ovary weight. 
Ima Rahmawati: Effectiveness of Maja Leaf (Aegle Marmelos) Extract to the Process of Infertilization

\section{Introduction}

The quality family is a prosperous, healthy, advanced, independent, has the ideal number of children, forward-looking, responsible, harmonious and devoted to God Almighty. In the new paradigm of the Family Planning Program, its mission greatly underscores the importance of respecting reproductive rights, as an integrated effort to improve family quality (Badan Pusat Statistik et al., 2015).

Every human being essentiallycraves a healthy and prosperous life to be born and inner. Health is one of the basic human needs, in addition to the need for clothing, food, shelter,and education, because only with good health conditions and a prime human body can carry out the process of life to grow and develop running all activities of his life. There is a libre "Health is not everything, but without your health cannot do anything, even everything that might disappear."

Health efforts, in this case, the use of traditional medicine is one of the seventeen kinds of provisions regulated by Law No. 36 of 2009 on health. Also, to obtain degrees made by the community occurs a change. Traditional medicine is the choice of some Indonesians as a complementary or subsidies on conventional medicine. The pharmaceutical industry and the contraceptive industry with a variety of products and high levels of prices that are sometimes difficult to reach by the community and do not guarantee any side effects, so it is necessary to examine plants that are natural, cheap, harmless and environmentally friendly (Yuningsih, 2012).

The use of natural materials as traditional medicine in Indonesia has been done by our ancestors since centuries ago where the plant as material. Herbal medicine has been widely accepted in almost all countries of the world. According to WHO, countries in Africa, Asia, and Latin America use herbal medicine as a complement to the primary treatment they receive. Even in Africa, as many as $80 \%$ of the population uses herbal remedies for primary treatment. Due to the failure of modern medicine for certain diseases such as cancer and wider access to information on herbal medicines worldwide (Oktora, Kumala, Lecturer, Study, \& University, 2006). Research on contraceptives derived from plants is still a priority because it is easy to get, cheap and low toxicity and no side effects (Sihombing, Akmal, Wahyuni, \&Nasution, 2010).

The use of natural materials, both as medicine and other purposes tends to increase, especially with the issue of back to nature and decreased the purchasing power of people against synthetic drugs. Traditional herbs and medicinal plants are widely used by middle-class people,especially in preventive, promotive and rehabilitative efforts. Many people assume that the use of medicinal plants or traditional medicine is relatively safer than synthesis drugs. It does not mean that medicinal plants or traditional medicine have no adverse side effects if the use is not appropriate.

Health efforts, in this case, the use of traditional medicine to obtain degrees made by the community occurs a change. Traditional medicine is the choice of some Indonesians as a complementary or subsidies on conventional medicine. Traditional medicine is one of seventeen kinds of health efforts arranged in Law Number 36 the Year 2009 on Health. The pharmaceutical industry and the contraceptive industry with a variety of products and high levels of prices that are sometimes difficult to reach by the community and do not guarantee any side effects, so it is necessary to examine plants that are natural, cheap, harmless and environmentally friendly (Yuningsih, 2012) .

Kanokporn et al., (2006), states that in India the Maja Leaf (Aegle Marmelos) is potentially used as a male contraceptive and herbal remedy to regulate birth and treat sexual diseases. Extracts of maja fruit in the form of herbal tea mixed with Stevia rebaudiana leaves can decrease the number of births and cause miscarriage (Remya et al., 2009).

The results of Hasrah's (1994) study of Maja Leaf (Aegle Marmelos) given in infusion mice method with concentrations of $20 \%, 30 \%, 40 \%$ and $50 \%$ can be used for abortiva and affect the number of children. In this study wanted to see the effect on other reproductive activities such as, the number of corpus luteum and ovarian weight.

The test results of Lupoel and Marmin Bioactivity Identification and Test of 
Ima Rahmawati: Effectiveness of Maja Leaf (Aegle Marmelos) Extract to the Process of Infertilization

Separation from Koerteks Aegle marmelos by Sugeng Riyanto and Mawardi Rahmani note that Maja Leaf (Aegle Marmelos) contains active ingredients such as $\beta$-sitosterol and stigmasterol. These active ingredients are steroidal (Riyanto, 2000). Phytosterols or steroids produced from plants have the efficacy of anti-fertility contraceptives that can stimulate progesterone and estrogen, if excessive products can inhibit ovulation (Riyanto, 2000).

The mechanism of action of antifertility substances to the ovaries can be shown its activity on inhibition of ovulation and steroidogenesis (Farnswoorth et al., 1975 \& Hafez 2000). This inhibition of ovulation as a result of inhibition of estrogen and progesterone production as reduced corpus luteum is formed is closely related to the amount of ovum that is ovulated. It will also lead to suppression of follicular numbers and progression resulting in decreased western ovaries and steroidogenesis (Ricards, 1980).

The purpose of this study was to determine the effect of Maja Leaf (Aegle Marmelos) extract on ovarian weight and number of female, white rat corpus luteum.

\section{Research Method}

This study used post test design only control group design. The subjects of the study were female Wistar female rats aged 8-10 weeks and had given birth weighing 200-225 grams. The sample size is 24 tails.

The samples were divided into four complete randomized groups namely;

Group 1 (Ko): Is a control group.

Group 2 (K1): Treatment group gaveMaja Leaf (Aegle Marmelos) extract at dose 0,5g $/ \mathrm{kg} \mathrm{BW}$.

Group 3 (K2): Represents the treatment group given Maja Leaf (Aegle Marmelos) extract at a dose of $1 \mathrm{~g} / \mathrm{kg} \mathrm{BW}$.

Group 4 (K3): Treatment group gaveMaja Leaf (Aegle Marmelos) extract with dose $1,5 \mathrm{~g} / \mathrm{kg} \mathrm{BW}$.

Maja Leaf (Aegle Marmelos) extracts are given when the rat reproduction cycle is in the proestrus phase. To know the phase of the reproduction cycle, then the animal tries to do vaginal smear first. Maja Leaf (Aegle Marmelos) extract gave per sonde appropriate dose for 12 days. After administration of Maja Leaf (Aegle Marmelos) extract ended, surgery and ovarian removal to be weighed and known ovaries weight of each sample, then made preparations with coloring to determine the number of corpus luteum. Provision of Maja Leaf (Aegle Marmelos) extract and ovarian removal and preparation of preparations were performed in embryology laboratory and histology laboratory of FKH Unair Surabaya.

The resulted data is normal and homogeneous distribution then tested by Analysis of variance (Anova) which if there is significant difference, then to know the difference between treatments in normal distribution data (ovary weight variables) and variation of data between homogeneous groups followed by LSD (Least Significant Difference) with significance level $\mathrm{p}<0.05$. Data analysis was done by computerized using SPSS version 17.

\section{Research Results}

The study was conducted for 19 days. At the end of the animal, experiment tries to be sacrificed for ovarium taking.

At the end of treatment (day 20), experimental animals group (Ko, K1, K2, $\mathrm{K} 3$ ) in doing surgery and subsequent ovarian ovaries in weighing.

Table 1 Mean and Standard Deviation Values of Ovarian Weight and Number of Corpus Luteum in Female Rats.

\begin{tabular}{cccc}
\hline N & Group & \multicolumn{2}{c}{ Rerata \pm SD } \\
\cline { 3 - 4 } & & $\begin{array}{c}\text { Corpus luteum } \\
\text { (gram) }\end{array}$ & Bobot ovarium (gram) \\
K1 & 6 & $35.50 \pm 0.84$ & $0.06 \pm 0.01$ \\
K2 & 6 & $2.83 \pm 0.75$ & $0.05 \pm 0.01$ \\
K3 & 6 & $1.67 \pm 0.82$ & $0.04 \pm 0.01$
\end{tabular}


Ima Rahmawati: Effectiveness of Maja Leaf (Aegle Marmelos) Extract to the Process of Infertilization

Table 2 Test Results Kolmogorov - Smirnov Test. and Levene Test on Ovarian Weights in Female White Rats.

\begin{tabular}{lcc}
\hline \multicolumn{1}{c}{ Variable } & $\mathbf{n}$ & Significance (p-value) \\
\hline Normality data & 24 & 0.979 \\
Homogenitias varians & 24 & 0.627 \\
\hline
\end{tabular}

Table 3 Results Kolmogorov - Smirnov Test. and Levene Test on the Corpus Luteum in the Female white Rats.

\begin{tabular}{lcc}
\hline \multicolumn{1}{c}{ Variable } & $\mathbf{n}$ & Significance (p-value) \\
\hline Normality data & 24 & 0.362 \\
Homogenitias varians & 24 & 0.672 \\
\hline
\end{tabular}

Table 4 Analysis of ANOVA Oneway Test of Ovarian Weight and Number of Corpus Luteum of the White Rat after Administration of Maja Leaf (Aegle Marmelos) Extract.

\begin{tabular}{lcc}
\hline \multicolumn{1}{c}{ Variable } & F-test & significance (p-value) \\
\hline Bobot ovarium & 4.892 & 0.010 \\
Jumlah Corpus Luteum & 6.118 & 0.004 \\
\hline
\end{tabular}

Table 5 Result of LSD variable of Ovary Weight Of Female, White Rat.

\begin{tabular}{ccccc}
\hline Group & K1 & K2 & K3 & K4 \\
\hline P1 & - & 0.182 & $0,006^{*}$ & $0,003^{*}$ \\
P2 & 0.182 & - & 0,109 & 0,062 \\
P3 & $0,006^{*}$ & 0,109 & - & 0,766 \\
P4 & $0,003^{*}$ & 0,062 & 0,766 & - \\
\hline
\end{tabular}

Table 6 Results of LSD Variable Number of Female Rat Corpus Luteum.

\begin{tabular}{|c|c|c|c|c|}
\hline Group & K1 & K2 & K3 & K4 \\
\hline K1 & - & $\mathbf{0 , 1 9 0}$ & $\mathbf{0 , 0 0 1 *}$ & $\mathbf{0 , 0 0 3}$ \\
\hline K2 & $\mathbf{0 , 1 9 0}$ & - & $\mathbf{0 , 0 2 8}$ & $\mathbf{0 , 0 5 5}$ \\
\hline K3 & $\mathbf{0 , 0 0 1 *}$ & $\mathbf{0 , 0 2 8}$ & - & $\mathbf{0 , 7 3 8}$ \\
\hline K4 & $\mathbf{0 , 0 0 3 *}$ & $\mathbf{0 , 0 5 5}$ & $\mathbf{0 , 7 3 8}$ & - \\
\hline
\end{tabular}

The results showed that the lightest ovarian weight is in the group $\mathrm{K} 3$ and $\mathrm{K} 4$ means the lower the ovary weight, the less the occurrence of fertilization. The less fertilization process, the higher the occurrence of infertility.

The results showed that the number of corpus luteum at least in the $\mathrm{K} 3$ and $\mathrm{K} 4$ groups means that fewer corpus luteum, the less fertilization occurs. The less fertilization process, the higher the occurrence of infertility.

ANOVA Assumption Test Results

Test of normality of data by using Kolmogorov-Smirnov got $p$-value value $0,979>\alpha(0,05)$ mean data is normal distribution. While the result of homogeneity test of variance by using Levene Test got p-value value, $0,627>\alpha(0,05)$ meaning homogeneous data variance. 
Ima Rahmawati: Effectiveness of Maja Leaf (Aegle Marmelos) Extract to the Process of Infertilization

Test of normality of data by using Kolmogorov-Smirnov got p-value 0,362> $\alpha(0,05)$ mean data is a normal distribution. While the result of homogeneity test of variance by using Levene Test got $\mathrm{p}$-value value, $0,672>\alpha(0,05)$ meaning homogeneous data variance.

\section{Anova Test Results}

Ovary weight

To know the differences between groups on ovarian weight and number of corpus luteum ANOVA test one way.

Based on the above table, on anova oneway test of ovarium weight of white rat after giving of Maja Leaf (Aegle Marmelos) extract obtained F-count value equal to 4,892 at ovarian weight with p-value $0,010<\alpha$ $(0,05)$, for corpus luteum variable, got result of $F$ value $-0,0118$ and p-value $0,004<\alpha$ $(0,05)$ can be concluded there is significant difference between groups. This means that administration of Maja Leaf (Aegle Marmelos) extract has a significant effect on ovarian weight and number of corpus luteum of the white rat

LSD (Least Significant Difference) Multiple Likelihood Analysis of ovarian weight and Number of Corpus Luteum Rats.

The result of LSD (Least Significant Difference) showed that there was a significant difference between ovarian weight in control group (K1) and Maja Leaf (Aegle Marmelos) extract dose $1 \mathrm{~g} / \mathrm{kg} \mathrm{BW}$ (K3), Maja Leaf (Aegle Marmelos) extract dose $1.5 \mathrm{~g} / \mathrm{kg} \mathrm{BW}(\mathrm{K} 4)$. It can be concluded that there is no difference between $\mathrm{K} 1$ and $\mathrm{K} 2, \mathrm{~K} 3$ and $\mathrm{K} 4$ differed significantly with $\mathrm{K} 1$ and $\mathrm{K} 2$

The result of LSD (Least Significant Difference) showed that there was a significant difference of corpus luteum in control group (K1) with Maja Leaf (Aegle Marmelos) extract dose 1g / kg BB (K3), Maja Leaf (Aegle Marmelos) extract dose 1.5 $\mathrm{g} / \mathrm{kg}$ BB (K4). Group of Maja Leaf (Aegle Marmelos) extract dose $0,5 \mathrm{~g} / \mathrm{kg}$ BB (K2) was significantly different with Maja Leaf (Aegle Marmelos) extract group dose 1 g / kg BW (K3).

\section{Discussion}

Maja Leaf (Aegle Marmelos) (Aeglemarmelos) is a natural ingredient that is widely used by the community as a traditional medicine such as fever, diarrhea, itching, other than that Maja Leaf (Aegle Marmelos)as well as herbal therapy to inhibit pregnancy and abortion (Orwa C, A Mutua, Kindt R, Jamnadass R, 2009). In this study aims to determine the effect of Maja Leaf (Aegle Marmelos) extract on ovarian activity that is seen from the ovarian weight.

The experimental animals used in this study were white rats (Rattus norvegicus) because these animals were anatomically gastrointestinal tracts that differed slightly from other mammals where the esophagus directly boils down to the stomach (Chauhan \& Agarwal, 2009), so the rat can not regurgitate the treatment Maja Leaf (Aegle Marmelos) extract through sonde. The sexes were chosen by females because the purpose of this study was to look at the results of ovarian organ ovulation inhibition that only female mice had.

\section{Effect of Maja Leaf (Aegle Marmelos) Extract on Ovarium Weight}

The result of ANOVA test showed that giving of Maja Leaf (Aegle Marmelos) extract affected ovarium weight of rat treatment ( $p$-value $<0,05$ ). When compared with control group, there was a decrease of mean ovarium weight of $12 \%$ from 0.06 gram down to 0.05 gram in group K1 given Maja Leaf (Aegle Marmelos) extract dose 0,5g / $\mathrm{kg}$ BW, decrease $15 \%$ from 0,06 gram become 0.04 gram in group K2 dose $1 \mathrm{~g} / \mathrm{kg} \mathrm{BW}$ and decrease $15 \%$ from 0,06 gram to 0,04 gram in group of $\mathrm{K} 3$ dose $1,5 \mathrm{~g} / \mathrm{kg} \mathrm{BW}$. Reduction of ovarian weight is caused by a decrease in the number of follicles and corpus luteum. The average decrease of corpus luteum occurred $12.3 \%$ from 3.50 fruit to 2.85 fruit in group $\mathrm{K} 1$ dose $0,5 \mathrm{~g} / \mathrm{kg} \mathrm{BB}$, decrease $20,9 \%$ from 3,50 fruit become 1,66 fruit in group of $\mathrm{K} 2$ dose $1 \mathrm{~g} / \mathrm{kg} \mathrm{BW}$, decreased $19.3 \%$ from 3.50 fruit to 1.83 fruit in group of $\mathrm{K} 3$ dose $1.5 \mathrm{~g} /$ $\mathrm{kg} \mathrm{BW}$.

The entry of steroids contained in Maja 
Ima Rahmawati: Effectiveness of Maja Leaf (Aegle Marmelos) Extract to the Process of Infertilization

Leaf (Aegle Marmelos) extracts causes reduced ovarian weight to affect ovarian function. Nalbandov 1990), the more functional ovaries are heavier,and the structures inside are larger. The reduced ovarian weight is due to decreased number of follicles and corpus luteum. The number of decreased follicles is due to the rise in estrogen in the blood as a result of suppression of FSH levels. The suppression of FSH levels causes retardation of follicular development. This obstacle is indicated by the decreasing number of corpus luteum in the three treatment groups. The ovarian weight of rats is closely related to follicular development. The weight of the ovaries will decrease if there is an emphasis on the number of follicles (Megawati \&Listyawati, 2010). The same opinion according to Farnsworth et al., (1978) and Cheeke (1989) states that plants containing steroids are estrogenic, affecting the development of follicles that affect the weight of the ovaries. This is related to the effects caused by the entry of phytosterol ( $\beta$-sitosterol and stigmasterol) contained in Maja Leaf (Aegle Marmelos) extract is causing estrogen levels in the blood is increased. This increase in estrogen can inhibit follicular development through suppression of FSH levels through negative feedback. This emphasis on FSH levels results in a disruption to follicle development as indicated by a decrease in the number of mature ovarian follicles. This is related to the effects of the entry of phytosterols ( $\beta$-sitosterol and stigmasterol) contained in Maja Leaf (Aegle Marmelos) extracts that can inhibit follicular development through suppression of FSH levels. This emphasis on FSH levels results in a decrease in the number of follicles and the corpus luteum of the ovary.

\section{Effect of Maja Leaf (Aegle Marmelos) Extract on Corpus Luteum Amount}

Statistical analysis of corpus luteum showed that giving of maja leaf extract had a significanteffect on decreasing corpus luteum amount of treatment rat $(\mathrm{p}>0,05)$.

This decrease in the number of corpus luteum is caused by the introduction of the antifertility substances of $\beta$-sitosterol and stigmasterol, and triterpene glycosides can form complexes with cholesterol resulting in changes in membrane permeability and suppress amino acid transport into cells. This results in the obstruction of RNA synthesis. The occurrence of RNA synthesis constraints results in the occurrence of mitotic fractures. The occurrence of mitotic inhibition continues with the inhibition of follicular proliferation and differentiation so that the egg can notcontinue its meiosis. Prosise meiosis 1, ovum occurs before ovulation, and meiosis twoprocessesis completed after fertilization.

Disruption of this process will fail the cooking of eggs which ultimately lead to no ovulation. If ovulation does not occur, corpus luteum is not formed (Novriyanti et al., 2014). In this study, the decrease in the number of corpus luteum is in line with the decrease of ovarian weight in the treatment group.

The decrease in ovarian weight, the number of ovarian follicles is followed by a decrease in the number of corpus luteum. Corpus luteum is formed due to hypertrophy and hyperplasia of ovulatory follicle granulosa cells (Chauhan \& Agarwal, 2009). This will result in decreased ovulation rate since many of the corpus luteum is closely related to the amount of ovum being ovulated.

\section{Conclusion}

Maja Leaf (Aegle Marmelos) extract (Aegle marmelos) can decrease ovarian weight,and corpus luteum amount in white rat means ovulation process does not occur. This is due to a decrease in the number of corpus luteum followed by a decrease in ovarian weight. So it can be concluded Maja Leaf (Aegle Marmelos) extract is effective toInfertility.

\section{References}

Badan Pusat Statistik, Badan Koordinasi Keluarga Berencanan Nasional, Departemen Kesehatan, Macro International, Badan Pusat Statistik Indonesia, Menua, D. A. N. P., ... Iba. (2015). KUALITAS SUMBER DAYA MANUSIA DALAM MENGGAPAI BONUS DEMOGRAFI Rachmawati Madjid. 
Ima Rahmawati: Effectiveness of Maja Leaf (Aegle Marmelos) Extract to the Process of Infertilization

Jurnal Populasi, 2(1), 102-114. https://doi. $\operatorname{org} / 2101018$.

Chauhan, A., \& Agarwal, M. (2009). Assessment of the contraceptive efficacy of the aqueous extractofAeglemarmelos Corr.leaves in male albino rats. Human Fertility. https:// doi.org/10.1080/14647270802657402.

Megawati, D., \& Listyawati, S. (2010). Siklus estrus dan struktur histologis ovarium tikus putih (Rattus Norvegicus). Skripsi, 7(April), 47-52. Retrieved from https://digilib. uns.ac.id/...=/Siklus-estrus-dan-strukturhistologis-ova...

Novriyanti, E., Sumarmin, R., Zayani, N., Studi, P., Fmipa, B., \& Negeri, U. (2014). Pengaruh Ekstrak Biji Kapas (Gossypium Hirsutum L.) Terhadap Reproduksi Mencit Betina ( Mus musculus L ., Swiss Webster, 4(1), 1-16.

Oktora, L., Kumala, R., Pengajar, S., Studi, P., \& Universitas, F. (2006). Pemanfaatan Obat Tradisional Dan Keamanannya. Majalah Ilmu Kefarmasian, 3(1), 1-7. https://doi. org/10.7454/PSR.V3I1.3394.

Orwa C, A Mutua, Kindt R , Jamnadass R, S. A. (2009). Aegle marmelos (L.) Correa Rutaceae Aegle marmelos (L.) Correa. Agroforestree Database, 0, 1-5.

Sihombing, W., Akmal, M., Wahyuni, S., \& Nasution, I. (2010). Efek Ekstrak Daun Pegagan Terhadap Perkembangan Sel
Spermatid Tikus (Rattus Norvegicus) The Effect of Centella Leaf Extract (Centella asiatica ( L .) Urban on, 71-76.

Yuningsih, R. (2012). Pengobatan Tradisional di Unit Pelayanan Kesehatan. Info Singkat Kesejahteraan Sosial, 4(5), 36-39.

Suherman, S.K, (2007), Estron, anti estrogen, progestin dan kontrasepsi oral dalamfarmakologi dan terapi, -5 th ,ed Jakarta. Departemen farmakologi dan terapeutik. Fakultas Kedokteran Universitas Indonesia.

Kanokporn S, Aritajat S, Saenpet S, Manosroi JA, (2006), 'Safety evaluation of aqueous Extracts from aeglemarmelos and stevia rebaudiana on reprodution of female rats', $J$ Pharmac. 37 : 3203-3205.

Remya, M Sharma, R.C., Shoaib, H. Asad, (2009), 'In vitro effect of aeglemarmelos on humanspermamotylity. J. Med Plant, Res: 1137-1139.

Riyanto S, Mawardi R, (2000), Isolasi senyawa korteks aegle marmelos dengan petroliumeter'. Yogjakarta. Fakultar Farmasi Universitas Gajahmada.

Farnswoorth N.R, Bingel A.S, CondelDengs, Wang. Y. Chen S.N. (1978), 'Objective to study the potential antivertility effect of the aqueous aeglemarmelos a potential agen for treating small cell'. J.Pharmac Sci, 64: 535548. 